\title{
KAVRAMSAL BİR SIPARİŞ KABUL/RED KARAR MODELİ
}

\author{
Bülent SEZEN \\ Gebze Yüksek Teknoloji Enstitüsü, İsletme Fakültesi, Dr.
}

\begin{abstract}
In this study, a conceptual model for constructing an order acceptance/refusal mechanism has been developed. Major factors affecting the decision of accepting or refusing an order, including product specifications, order quantity, price, due date, current work load at the job shop, and customer value, are considered in building the conceptual model. Managerial and financial benefits resulting from using such a decision mechanism have been identified.
\end{abstract}

\section{GíRiș}

Günümüzde artarak kendini hissettiren rekabet nedeniyle, müşteriler siparişlerinin daha güvenilir, daha çabuk ve daha ucuza temin edilmesini talep etmektedirler. Firmalar bu talebi karşılayabilmek amacıyla üretim zamanlarını kısaltmak ve böylece atölye performansını artırmak amacını gütmüşlerdir. Üretim zamanlarının uzamasına neden olan en önemli faktörün imalat esnasında bir dağ gibi biriken yarı mamul stokları olduğu gerçeği literatürde yaygın olarak kabul görmüştür [1]. Bu nedenle, yarı mamul stoklarmın kontrol altında tutulması, yani diğer bir deyişle makul bir seviyede tutulması, üretim zamanlarını kısaltarak verimliliği artırabilir. Yarı mamul stoklarını kontrol altında tutmanin bir yolu, imalathaneye giren üretim siparișlerinin kontrol altında tutulmasıdır. Siparişlerin izlenmesi ve kontrol altında tutulması ile ilgili akademik literatür, genellikle işletmeye giren her siparis talebinin kabul edildiğini varsaymaktadır [2]. Halbuki, bazı durumlarda üretim kapasitesi müşteri talebini karşılamada yeterli olmayabilir. Eğer bu durum söz konusu ise, ve üretim kapasitesini kısa vadede artırmak da mümkün değilse, şüphe yok ki, siparișlerin bir kısmı ya gecikecektir ya da kaybedilecektir. Bu nedenle, üretim kapasitesinin dinamik olarak göz önünde tutulması ve bu kapasiteye dayali olarak gelen siparişlerin kabul veya red edilmesi yoluyla toplam üretim kapasitesi daha verimli kullanılabilir.

Literatürde siparişlerin geç teslim edilmesi durumunun bazı hallerde siparişi ret etme durumundan daha kötü sonuçlar doğurabileceğini savunan çalışmalar mevcuttur [örneğin, 2-4]. Geç teslimat ile müşteriyi zor durumda bırakmaktansa, siparişi baștan kabul etmemek bazen daha akılcı bir çözüm olabilir.
Siparişlerin kabul veya red edilmesi kararını etkileyebilecek başhica faktörler şöyle sıralanabilir: 1) ürün özellikleri 2) sipariş miktarı 3) fiyat 4) teslim zamanı 5) atölyedeki mevcut iş yükü 6) müşterinin firma gözündeki değeri. Bu faktörler listesini çoğaltmak mümkündür. Bütün bu faktörlerin etkisi ile siparișlerin kabul/red edilmesi hakkunda bir karar verilebilir. Fakat bu karar, işletmenin farklı departmanlarından (özellikle satış ve üretim departmanlarından) sağlanacak bilgiler ışı̆̆nda ve stratejik amaçlar dogrultusunda belirlenmiş olan performans değerlerine katkıda bulunacak şekilde alımmalıdır. Bu nedenle, siparişler üretim departmanına gönderilmeden önce bir sipariş kabul/red mekanizmasından geçirilmeli ve gerekirse sipariş red edilmelidir.

Akademik literatürde, yukarıda sözü edilen sipariş. kabul/red mekanizmasına örnek olabilecek smırlı sayıda çalışma mevcuttur. Yukarıda öngörülen altı faktörün hepsini birden göz önünde bulundurarak farklı türde mekanizmaların karşılaştırmalı olarak analizini yapan bir çalışmaya ise rastlanılmamıştır. Bu nedenle, burada amaçlanan şey, sözü edilen sipariş kabul/red mekanizması için tüm faktörlerin (ürün özellikleri, sipariş miktarı, fiyat, teslim zamanı, atölyedeki mevcut iş yükü, müşterinin firma gözündeki değeri) göz önünde tutulduğu kavramsal bir model geliştirmektir.

Geliştirilen kavramsal modelin hayata geçirilmesi ile bir işletmeye gelen sipariş akışı kontrol altında tutularak müşterilere taahhüt edilen teslim zamanlarına daha kolay riayet edilebilecektir. Yoğun rekabet altında olan işletmelerde, müşterilerin arzu ettikleri teslim zamanlarından daha geç gerçekleştirilen teslimat nedeniyle, müşteri hayal kırıklığına uğrayarak bir dahaki siparişini başka bir işletmeye verebilir. Müşterileri hayal kırıklı̆̆ına uğratmamak için, işletme yöneticilerinin, siparişlerin teslim zamanlarında yetiştirilip yetiştirilemeyeceğini, istenen özellikte ürünün temin edilip edilemeyeceğini, ve en önemlisi, mevcut üretim programının yeni siparişi zamanında bitirmeye müsait olup olmadığı gibi konularda bilgi sahibi olmaları ve optimal bir karar vermeleri gerekmektedir. Gelen siparişlerin sayısı ve sıklığı arttıkça bu karar daha da zorlaşacaktır. Bu nedenle, burada sunulan model, yoğun 
rekabet altında olan işletmelerdeki yöneticilerin siparişleri kontrol altında tutabilmesi konusuna 1şık tutan önemli bir araç olacaktır.

Siparişlerin red edilmesi durumu ancak pazar talebinin üretim kapasitesini aştığı durum için geçerlidir. Eğer talep az ise, zaten gelen siparişlerin red edilmesi düşünülemez. Talebin üretim kapasitesini aştığı durumda, işletme bu siparişlerin bir kısmını doğal olarak geri çevirecektir. Hangi siparişlerin geri çevrilip hangilerinin kabul edildiği konusunda verilen karar, işletmenin kazançlarını, maliyetlerini, gelecekteki müşteri potansiyelini ve genel üretim verimliligini etkileyecektir. Geliştirilen modelde, alınan kabul/red kararı sonucunda etkilenecek olan bu gibi performans ölçülerine de yer verilmektedir.

\section{LITTERATÜR TARAMASI}

Literatürde sipariş kabul/red sistemlerini incelemiş bulunan araştırmacıların konuya yaklaşım şekillerini üç ana grupta sinıflandırabiliriz:

a) Üretim kapasitesine dayalı sipariş kabul/red mekanizmaları,

b) Fiyata (veya marjinal kâra) dayalı sipariş kabul/red mekanizmaları ve

c) Hem uretim kapasitesine hem de fiyata dayalı sipariş kabul/red mekanizmaları.

Bu sınıflandırmayı yapmaktaki gerekçemizi kısaca açıklamakta fayda vardır. Şöyle ki, geçmiş̧eki araştırmaların bir kısmı, sipariş kabul/red kararı için sadece atölyedeki mevcut iş yükünü göz önünde bulundurmuş ve eğer, yeni gelen sipariş nedeniyle iş yükü belirli bir limitin üstüne çıarsa, siparişi red etme eğiliminde olmuşlardır. Bu türden olan yaklaşımlara biz, üretim kapasitesine dayalı sipariş kabul/red mekanizmaları adını verdik. Diğer yandan, geçmişteki araştırmaların diǧer bir kısmı da, sipariş kabul/red kararı için sadece fiyat faktörünü göz önünde bulundurmuş ve eğer, yeni gelen sipariş için teklif edilen fiyat veya beklenen getiri değeri belirli bir limitin altında ise, sipariş red edilmiştir. Bu tür mekanizmalara da fiyata dayalı sipariş kabul/red mekanizmaları adınt verdik. Son olarak, bir kısım araştırmacılar da, hem fiyat hem de üretim kapasitesi ile ilgili faktörleri bir arada kullanmışlardır. Bunlar da, sınıflandırmamızdaki üçüncủ grubu temsil etmektedir.

Gerçek hayattaki karar mekanizmalarını ele alacak olursak, sipariş kabul/red sistemlerinin fiyat ve kapasiteye dayalı olarak iki gruba ayrılmış olması, satış ve üretim departmanları arasındaki ilişkilerin seviyesini de açıklayabilir. Öyle ki, sadece fiyata dayalı bir sistem, sipariş kabul/red kararının sadece satış departmanı tarafindan alındığı anlamına gelebilir. Diğer yandan, sadece üretim kapasitesine dayalı bir karar sistemi ise, kabul/red kararının sadece üretim departmanı tarafindan alındığı anlamına gelebilir. Her iki faktörün kullanıldığı durum ise, satış ve üretim departmanlarının bir arada karar aldığı anlamına gelebilir. Şimdi, sipariş kabul/red mekanizmalarma yönelik olarak akademik literatürde bu uiç yaklaşımı kullanan araştırmaların bir degerlendirmesi yapilacaktır.

\section{A. Üretim Kapasitesine Dayalı Sipariș Kabul/Red Mekanizmalan}

Philipoom ve Fry [2], sipariş kabul/red kararı için üç yöntem ileri sürmüş ve bir simülasyon modeli kullanarak bu yöntemleri, geç teslim edilen siparişlerin yüzdesi ve ortalama maliyet seviyeleri açismdan birbirleriyle kıyaslamışlardır. Sipariş kabul/red karar yöntemlerinin birincisi, atölyedeki toplam iş yüküne göre kabul/red kararını vermektedir. Bu yöntemde, [atölyedeki mevcut toplam iş yükü + yeni siparişin gerektireceği iş yükü] toplamı önceden belirlenmiş bir limitin altında olmadıkça hiçbir sipariş kabul edilmemektedir. İkinci $\mathrm{kabul} / \mathrm{red}$ karar yöntemi ise, sadece yeni gelen siparişin ziyaret edeceǧi makinelerdeki toplam iş yüküne bakmaktadır. Bu makinelerin her biri için mevcut iş yükü, bu makinelere yơnlendirilecek olan tüm işlerin işlem zamanlarınin toplanması yoluyla bulunmaktadır.

Eğer söz konusu siparişin rotası üzerinde bulunan herhangi bir makineđeki iş yükü, önceden belirlenmiş olan bir limiti aşıyorsa, sipariş red edilmektedir. Üçüncü yöntem, bir sipariş kabul/red mekanizması olmayıp, siparişleri belirli bir oranda rasgele red eden bir yöntemdir. Bu yöntem, diğer iki yöntem ile, kabul/red mekanizmasının olmadığı durumun karşılaştırılması amacıyla bir kıyaslama aracı olarak kullanılmaktadır. Araştırmanın sonuçlarına göre, sipariş rotası uzerindeki toplam iş yüküne bakılarak siparişlerin kabul/red edildiği ikinci yöntem diğerlerine göre daha iyi sonuçlar vermiștir.

Wester ve diğerleri [5], kurulum ve teslim zamantarınin bulunduğu sipariş için üretim sistemlerinde, monolitik, hiyerarşik, ve miyopik olmak üzere üç farklı sipariş kabul stratejisini incelemişlerdir. Monolitik sipariş kabul stratejisinde, sipariş̧ kabul/red kararı için, önceden kabul edilmiş siparişlerin tümünün ve yeni kabul edilecek olan siparişin içine katıldığı en son üretim programının sağladığı detaylı bilgilere bakılır. Hiyerarșik sipariş kabul/red kararı için sadece global kapasite yüklemelerine bakılır. Burada yine detaylı üretim programlama vardır, fakat sipariş kabul/red kararı için bu üretim programından faydalanılmaz. Miyopik stratejide ise, sipariş $\mathrm{kabul} / \mathrm{red}$ kararı hiyerarşik stratejideki gibi olmakla beraber, burada, üretim programlama sadece bir sonraki kabul edilecek sipariş için yapılır ve daha basit kurallara dayalıdır. 
$\mathrm{Bu}$ üç farklı sipariş kabul stratejisinin performansı simülasyon yoluyla kıyaslanmıştır: Teslim zamanları sıkı ve gevşek olarak iki kademeli düşünülmüştür. Ayrica, ürün türü sayısının iki ve beş olduğu iki ayrı durum ele alınmıştır. Performans ölçüm kriteri olarak sadece üretim sisteminin kullanım oranı (utilization) seçilmiştir. Rapor edilen sonuçlara göre, uç farklı stratejinin performansları arasındaki farklar oldukça azdır. Sadece, sıkı teslim zamanları için ve ürün türư sayısmın yüksek olduğu durumda, monolitik yaklaşım diğerlerine göre çok daha iyi sonuçlar vermiştir. Wester ve diğerlerinin [5] simülasyon modelinde, her siparişin zamanında teslim edileceği şekilde bir üretim programı belirlenmekte ve böylece geç teslimat gerçekleşmediği varsayılmaktadır. Erken biten siparişler için de bir maliyet düşünülmemiştir. Sipariș kabul stratejileri, eğer herhangi bir sipariş geç teslime neden olacaksa, bu siparişi kabul etmemektedir. Sadece üretim sisteminin kullanım oranı kriterini kullanan bu çalışmada, teslimat gecikmelerine ilişkin performans kriterleri de göz ardı edilmiştir.

Kate [6], siparis kabul/red kararının alımmasında iki farklı yapısal yaklaşım olduğunu ileri sürmüştür: hiyerarşik yaklaşım ve bütünleşmiş yaklaşım. Hiyerarşik yaklașımda, sipariş kabulü ile üretim programlama işlevleri farklı hiyerarşik seviyelerde olup birbirlerinden bağımsızdırlar. Bütünleşmiş yaklaşımda ise, sipariş kabulü ve üretim programlama işlevleri bütünleşmiş bir durumdadır. Sipariş kabul/red kararı bu bütünleşmiş departmandan çıkar. Hiyerarşik yaklaşımda, Philipoom ve Fry'ın [2] çalışmasında olduğu gibi, atölyedeki mevcut iş yükü ve yeni gelen siparişin gerektirdiği iş yükünün toplamı, önceden belirlenmiş bir limiti aşmiyorsa, sipariş kabul edilir. Üretim program periyodik olarak güncellenir. Bütünleşmiş yaklaşımda, her yeni sipariş gelișinde, bu yeni siparişi de içeren yeni bir üretim programı yapılır. Sonra, yeni program için, siparişlerin erken ve geç teslim edilme maliyetlerine bakılarak sipariş kabul veya red edilir. Eger, yeni programm maliyet artışı kabul edilebilir bir seviyede ise, yeni üretim programı uygulanır. Aksi halde, sipariş kabul edilmez ve eski program uygulanır. Bu iki yaklaşim, bir simülasyon modeli kullanilarak, ortalama maliyet ve teslim zamanı performansı bakımından birbirleriyle kıyaslanmıştır. Beklenen durumun aksine, genel olarak, bütünleşmiş yaklaşım, hiyerarşik yaklaşıma göre daha üstün olmamış, neredeyse iki yaklaşım çok yakın sonuçlar vermiştir. Fakat, bu sonucun bir istisnası olarak, iş yükünün yüksek ve toplam üretim zamanının kısa olduğu durumda bütünleşmiş yaklaşımın hiyerarşik yaklaşıma göre daha üstün performans gösterdiği rapor edilmiştir. İs yükünün yüksek ve toplam üretim zamanlarının kısa olması hali, giriş bölümünde tanımlanan ve araştırmamızın hedef aldığı, yoğun rekabet altında bulunan ve üretim kapasiteleri talebi karşllamada yetersiz olan işletmelerin tipik bir özelligidir. Bu tür imalat sistemlerinde üretim programlaması ne derece iyi yapılmıș ise, genel işletme performansı da o derece iyi olacaktır. Çünkü iş yükünün fazla olmasi, bu işlerin hangi öncelikte imalathaneye alınacă̆ probleminin önemini artıracaktır. Bu nedenle, bu tür ișletmeler için bütünleşmiş yaklaşımın kullanılması doğal olarak daha avantajlı olacaktır. Ayrıca, Kate'in [6] çalışmasında tek makineden oluşan bir model kullanıldığı için, üretim programlamanın ve bütünleşmiş yaklaşımın işletmeye sağlayacağı değer (çok makineden oluşan bir sisteme göre) daha azmıș gibi görünebilir.

Lee ve Kim [7], esnek üretim sistemlerinde çokdönemli sipariș seçim probleminin ve iş yükleme probleminin beraber çözümü için bir prosedür geliştirdiler. Çok-dönemli sipariş seçim problemi, bir sonraki planlama ufku içinde, her bir dönemde üretilecek siparişlerin seçilmesi olarak tanımlanmıştır. İş yükleme problemi de, seçilen siparişlerin makinelere tahsis edilmesidir.

Gelistirilen prosedürde, önce, makinelerin kapasite kısıt bilgileri ve yeni siparişler hakkındaki veriler kullanılarak, çok-dönemli sipariş seçim problemi çözülür ve her dönemde üretilecek olan siparişler belirlenir. Sonra, bu çözümde seçilmiş olan siparişler için iş yükleme problemi çözülür. Eğer, makine kapasitelerine uygun bir iş yükleme planına ulaşılırsa prosedür sonlanır. Aksi halde, çok-dönemli sipariş seçim problemi değiştirilerek yeniden çözülür ve döngü tekrarlanir. Prosedürün üçüncủ aşaması olan problemi değiștirerek yeniden çözme aşamasında dört farklı yöntem öne sürülmüș ve bu yöntemler birbirleriyle kıyaslanmıştır. Genel olarak bu çalışmada, çözüm teknił̧i olarak tam sayılı programlama tekniği kullanılmış ve amaç olarak erken teslim ve geç teslim maliyetleri ile bir siparişin kabul edilmeme maliyetinin minimize edilmesine çalışılmıştır.

Kern ve Guerrero [8], siparișe göre montaj türü imalat sistemlerinde talep yönetimi sürecini matematiksel bir model olarak formüle etmişlerdir (Ayrıca [9]'a da bakınız). $\mathrm{Bu}$ modelde odaklanılan nokta, siparişlerin $\mathrm{kabul} / \mathrm{red}$ edilmesi ve kabul edilen siparişler için mevcut kapasitenin kullanılmasına yönelik bir kontrol mekanizması oluşturmaktır. Kapasitelerin bazı durumlarda önceki dönemde kabul edilmiş siparişlere, bazı durumlarda alt modüllerin (ürünü oluşturan alt modüller) üretimine, bazı durumlarda da henüz bir sipariş olmadan üretimi tamamlanan (Available to Promise) ürünlere ayrılabileceği düşünülmủştür. Montaj ve alt modül üretimi için gerekli kapasitelerin eşit değerde olduğu varsayılmıştır. Kern ve Guerrero [8], geliştirdikleri modelde siparişlerin ya tamamen kabul edileceğini ya da tamamen red edileceğini varsaymış ve siparişlerin kısmen karşılanması olasılığını göz ardı etmişlerdir. Gelen siparişler, bitmiş ürün stoklarından, alt modül kapasitelerinden ve yarı mamul "stoklarmdan karşılanabilmektedir. Ayrıca, bu kaynaklardan sağlanan urünler belli bir zaman diliminden ya önce, ya sonra ya da tam o zaman diliminin bitiminde teslim edilebilmektedir. 
Bu ulç farklı durumun ortaya koyacağı maliyetler göz önünde bulundurularak ve siparişlerin kabul ve red edilmesi durumu matematiksel modelde 0 ve 1 ile temsil edilerek, tamsayılı programlama yöntemiyle örnek bir problem çözülmüşstür. Modelde geç teslimat maliyeti, siparişin red edilme maliyeti ve elde tutma maliyeti hesaba katılmıştır.

Buraya kadar değerlendirdiğimiz akademik çalışmalar, sadece üretim kontrolü ile ilgili kapasite kısıtlarını göz önünde bulundurarak sipariş kabul/red kararını vermeye yöneliktir. Halbuki, siparişlerin degerlendirilmesinde teklif fiyatı ya da marjinal getiri faktörü de önemli bir etken olabilir. Şimdi, sadece fiyat faktörüne bakarak sipariş kabul/red kararını vermeye yönelik olan akademik çalışmalara yer verelim.

\section{B. Fiyata (veya marjinal kara) Dayalı Sipariş Kabul/Red Mekanizmaları}

Balachandran ve. Schaefer [10], bir üretim sistemindeki siparişlerin optimal kabul probleminin çözümü için lineer olmayan bir kuyruk programlama modeli geliş̧tirmişłerdir. Siparişler belli sayıda sınıfa ayrılmaktadır. Problemin çözümünde, her sınıftan ne oranda sipariş kabul edileceği ortaya çıkarılmaktadır. Bu yaklaşımda, siparişler tek tek ele alınmayıp, siparişlerin hepsi birden ele altnarak, bunların içinden optimal bir karışım seçilmektedir.

Modelin amaç fonksiyonu, beklenen getirileri maksimize etmey่e yönelik olup, bu değer, siparişlerin beklenen toplam getirisinden, gecikme maliyetleri ve sermayenin firsat maliyeti çikarılarak elde edilmektedir. Bazı durumlarda, herhangi bir ürün sınıfina ait hiçbir siparişin kabul edilmemesi şeklinde bir optimal sonuca da ulaşllabilmektedir. Modelde, bir defada sadece bir tek ürünü işleyebilen basit bir üretim sistemi varsayılmıştır.

Matsui [11] sipariş seçim politikalarını statik ve sıralı (dinamik) olmak üzere ikiye ayırarak, uzun dönemdeki ortalama getiriyi maksimize etme problemini iki ayrı semi-Markov karar süreci şeklinde formüle etmiştir. Statik seçim politikasında, bir grup sipariş, sadece kabul edilmiş herhangi bir siparişin üretim sürecine başlanılmadan önce kabul/red karar süreci içine alınabilmektedir. Üretim süreci esnasında gelen siparişler bekletilmektedir. Bu nedenle, buna periyodik seçim politikası da denebilir. Sıralı (dinamik) seçim politikasında ise, sipariș seçimi, her bir sipariş için ayrı ayrı ve siparişin geldiği anda (dinamik olarak) yapılır. Her iki seçim politikasında da bir seçim kriteri (kontrol değişkeni) kullanılmış olup, eğer bir siparişin beklenen getirisi bu seçim kriterinin değerinden yüksek ise sipariş kabul edilmiş, düşük ise red edilmiştir.
Gelen siparişlerden hemen üretime alınmayanlar bir sipariş kuyruğuna alınmaktadır. $\mathrm{Bu}$ kuyrukta bekleyecek siparişlerin sayısı sınırlı tutulmakta ve bu sayıdan sonra gelen siparişler kabul edilmeyip kayıp sayılmaktadır. Sipariş gelişleri arası sürenin Poisson dağllımma uyduğu varsayılmış ve formülasyon için tek süreçli basit bir üretim sistemi kullanılmıștır. Matsui'nin [11] vardığı sonuca göre, dinamik seçim politikasının statik seçim politikasma göre daha yüksek getiri oranları vermesine karşın, dinamik seçim politikası, belirlenen seçim kriterine daha fazla duyarlı olmaktadır. Bu da, dinamik seçim politikasının her zaman daha iyi bir politika olmadığ anlamına gelir. Ayrıca, seçim kriterinin, kuyrukta bekleyen sipariş sayısına bağlı olarak değiştirilmesi gerektiği de vurgulanmıștır. Öyle ki, eğer kuyrukta bekleyen sipariş sayısı az ise seçim kriterinin değeri düşürülmeli, fazla ise yükseltilmelidir. Örneğin, kuyrukta bekleyen hiçbir sipariş yok ise, yüksek bir seçim kriteri nedeniyle gelen siparişin red edilmesi yanlış bir karar olacaktır. Böyle bir durumda seçim kriterinin degeri düşürülmelidir.

Matsui [12] sipariş seçim problemi için stokastik bir model (semi-Markov karar modeli) geliştirmiş ve bu modelde, sipariş kabul/red kararı için siparişin marjinal getirisine bakmıştır. Sipariş seçim politikaları iki sınıfa ayrılmıştır: periyodik seçim politikası ve dinamik seçim politikası. Dinamik seçim politikasında her yeni sipariş gelişinde sipariş kabul/red kararı anında yapılırken, periyodik seçim politikasında, bir dönem boyunca gelen siparişler toplanır ve dönem sonunda seçim yapılır. Modelde, kabul edilen siparişlerin sayısına (backlog) bağlı olarak değişen bir kontrol değişkeni bulunmakta ve eğer marjinal getiri bu değerden düşük olursa sipariş red edilmekte, yüksek olursa kabul edilmektedir. İki farklı seçim politikası (periyodik ve dinamik) ile bu kontrol deģişkeninin farklı kombinasyonları kullanılarak altı çeşit sipariş seçim politikası türetilmiş ve bu politikalardan hangilerinin optimal sonuç verdiği tespit edilmeye çalışılmiştır.

Matsui, Yang ve Miya [13] periyodik seçim politikasını kullanarak, sipariş seçimi ve farkıı işler arası geçişlerin bulunduğu bir üretim sisteminde, marjinal getiriyi maksimize etmeyi amaçlayan stokastik bir model geliştirdiler. Stokastik modelin iki alt-amaç fonksiyonu a) kabul edilen ortalama fiyatın maksimizasyonu ve b) ortalama üretim maliyetinin minimizasyonu olarak belirlenmiştir. Gelen siparişler, kabul edilmiş siparişlerin sayısına bağlı olarak deģişen iki seçim kriteri baz alınarak kabul veya red edilmektedir. Bu iki kriter iki ayri fiyat seviyesini (c1 ve c2) temsil etmektedir.

Öyle ki, eğer birikmiş sipariş sayısı belli bir seviyeden aşağıda ise $(\mathrm{i}<\mathrm{i} 1)$ üretim için sadece fiyatı cl'in uzerinde olan siparişler seçilmektedir. Eğer bu seviye aşılmış ise (i > i1), fiyatı c2'nin altında olan siparişler kabul edilmemektedir. 
Stokastik model, satıs ve üretim departmanlarının bir arada ve ayrı olarak faaliyet gösterdiği iki farklı durum için ayrı ayrı formüle edilmiş ve bu iki durum birbiriyle kyyaslanmıştır: Gelen siparişler arasından red edilenler kazanç kaybi olarak düşünülmüş ve siparişleri red edilen müşterilerin başka firmalarla anlaştı̆̆ varsayılmıştır.

$\mathrm{Bu}$ kısımda değerlendirdiğimiz akademik çalışmalar, bir önceki kısımda incelenenlerin aksine, sadece fiyat veya marjinal getiri faktörünü kullanan sipariş kabul/red mekanizmaları tasarlamışlardır. $\mathrm{Bu}$ çalışmalarda üretim kapasite kısıtları göz önünde bulundurulmamış ve daha çok, maliyetlerin minimizasyonu ve getirilerin maksimizasyonu gibi problemler çözülmeye çalışılmıştır.

\section{Hem Üretim Kapasitesine Hem de Fiyata Dayalı Sipariş Kabul/Red Mekanizmaları}

Harris ve Pinder [14] daha çok hizmet endüstrilerine uygulanmakta olan gelir yönetimi yaklaşımlarını siparişe-göre-montaj tipi imalat sistemlerine uygulamışlardır. Gelir yönetimi, mevcut üretim kapasitesinden elde edilecek olan net gelirleri maksimize etmek amaciyla, pazarlama, finans ve üretim işlevlerini bütünleștiren bir sipariş kabul/red sürecidir. Fiyat farklılaştırma stratejileri ile kapasite planlamayı bir arada kullanarak farklı müssteri gruplarına farklı alternatifler sunar. Gelir yönetimi sisteminde, sonradan gelebilecek acil mưşteri siparişleri için önceden belli bir seviyede kapasite rezervi yapılır. Gę̧ gelen müşteriler daha yüksek fiyat ödemeyi göze aldıkları için, önceden ayrılan kapasite bu siparişler için kullanılabilir.

Harris ve Pinder [14], gelir yönetiminin bu prensibinden yola çıkarak, iki farklı ürün sınıfına (normal ve acil) ait talep fonksiyonları ve üretim kapasiteleri ile ilgili parametreler verilmişken, her iki ürün smıfinnn optimal fiyatını ve ürünlere tahsis edilmesi gereken kapasite miktarlarm hesaplayan formüller geliştirmişlerdir. Belirlenen bu fiyat seviyeleri, sipariş kabul/red kararı için temel teşkil etmektedir. Eğer düşük kar paylı bir ürün smufina olan talep beklenilen seviyeyi aşarsa, bu ürün sınıfina ait siparişler artık kabul edilmez (satışlar durdurulur).

$\mathrm{Bu}$ yaklaşımda kullanılan sipariş kabul/red mekanizması fiyat ve kapasite dışındaki faktörleri (teslim zamanları, mevcut iş yükü, vb. gibi) hesaba katmamıştır. Ayrıca, her gelen sipariş ayrı ayrı değerlenđirilmeyip, talep belli bir seviyeyi aştı ı̆ında tüm siparişler red edilmektedir. Fransoo [15] akış türü proses endüstriler [Proses endustrileri, kanștırma, ayırma, șekillendirme veya kimyasal reaksiyonlar yoluyla malzemelere değger katan is türlerini kapsar. Surreçler ya sürekli ya da lot şeklinde (kesikli) olabilir. Genellikle yüksek yatırım ve esnek olmayan sürę̧ kontrol゙ gerektirir. Örnek olarak gida turunlerinin, kağst, kimyasallar, lastik, vb. uretimi bu türdendir.
(Koene, 1988) Akış tipi proses endastrilerde işlem sayısı bir ya da çok azdır ve benzer arunler için işlem sırası aynıdır (őrnek: cam ve kağıt uretimi] için sipariş kabul ve üretim programlama fonksiyonlarım içeren, tek makine - çok ürün sistemlerine yönelik genel bir üretim planlama ve kontrol modeli geliștirmiștir. Fransoo bu modeli Bitran ve Hax'm [16] öne sürmüş olduğu Hiyerarşik Üretim Planlama prensiplerine uygun olarak tasarlamış ve üç aşamalı bir hiyerarşi modeli kurmuştur. Bu modelin ilk seviyesinde parametreleri belirleme, ikinci seviyede sipariş kabul fonksiyonu ve üçüncü seviyede ise üretim programlama bölümleri bulunmaktadır.

Fransoo'nun [15] en önemli bulgusu, üretim çevrim zamanındaki [Çevrim zamanı aynı urünün birbirini izleyen iki uretimi arasında geçen zaman olarak tanımlanmaktadir. Ingilizce literatürde "cycle time" olarak kullanımaktadır] kisa dönemli degişimlerin, uzun vadede düşük servis performansina neden olduğudur. Bu nedenle Fransoo, modelinde çevrim zamanların kontrol altenda tutmuştur. Bunu da talep yöneticisinin sipariş akışını kontrol etmesiyle sağlamıştır. Sürekli olarak aktif bułunması gereken müşteri sipariş kabul fonksiyonunun ana amacı, en azından hedeflenen satış seviyesine ulaşacak şekilde gelen siparişleri kabul etmektir. Bunun yanında, sistemin uzun vadeli amaçlarına engel olmayacak kisa vadeli tüm fursatlar da değerlendirilmelidir. Fransoo modelinde esneklik kavramına da yer vermiştir. İki tür esneklik söz konusu olabilir: üretim kapasitesinin esnekliği ve karışım esnekliği. Üretim kapasitesi esnekliği üretilebilecek toplam ürün sayısının değıștirilebilmesidir. Kapasitenin sabit olduğu durumlarda bu esneklik var olamaz. Talep yöneticisinin kapasitede değişiklik yapabilmesi söz konusu değildir. Karışım esnekliği ise var olan kapasitenin farkh ürünler arasında değişik kompozisyonlarda paylaşlabilme olanağıdır. Talep yöneticisi, siparişleri kabul veya reddederek bu karışım esnekliğinden faydalanabilir. Böylece, kısa vadedeki müşteri siparişlerine cevap vermede mevcut kapasiteyi en etkin şekilde kullanmak mümkün olabilir.

Fransoo'nun [15] geliştirdiği modelin en önemli farkı, sadece akış tipi proses endüstrileri için düșünülmüş olmasıdır. Bu tip sistemlerde üretim kontrolü, farklı çok sayıda ürün, tek makine, yüksek kurulum [Kurulum kelimesi ile "makine kurulumu" kastedilmektedir. Bu kelimenin ingilizce literatürdeki karşılığ "setup" kelimesidir] zamanları gibi özelliklere sahiptir. Bu ortamlarda talep seviyesi kullanılabilir üretim kapasitesine çok yakın olmaktadır. $\mathrm{Bu}$ durum, talebin ve siparişlerin yönetilebilmesi için uygun bir zemin teşkil eder. Çünkü talebin bir kısmını reddedebilmek için talebin kapasiteyi aşması veya yakın olması şartı gerekir.

Fakat bu özellik sadece proses endüstrilerine özgü değildir. Talebin kapasiteye yakın olduğ diğer bir alan da siparişe-göre-montaj [Siparişe-göre-montaj terimi İngilizce literatürde "assemble-to-order" olarak geçmektedir] türü imalat sistemleridir. Fransoo'nun da [15] belirttiği gibi bu model 
üretim kontrolü perspektifinden bakıldığında iyi performans gösterse de, yönetim perspektifinden bakıldığında, hangi müşteri siparișlerinin kabul edilip hangi müşteri siparişlerinin red edileceğine karar vermek oldukça zordur. Firmanın müșteriye verdiği değer ya da öncelik bu modelde de göz ardı edilmiştir. Diğer yandan, müşteri davranışlarının seyri de dikkate alınmalıdır. Müșterilerin gelecekte nasıl davranacaklarının tahmin edilmesi kritik bir öneme sahiptir. Gelecek hakkındaki belirsizlik aslında belirli bir risk faktörüdür. Bu faktörün de sipariş kabul / red kararını etkileyen faktörler içinde yer almasi gerekir.

Moodie ve Bobrowski [4] bir firmanın geçmişteki sipariş teslimat performansının gelecekteki potansiyel müşteri siparişleri üzerine etkisi üzerinde çalışmışlardır (Ayrıca bakınız: Moodie [17]). Bu çalışmada sipariş teslimat performansını etkileyen en önemli faktörler olarak taahhüt edilen teslim zamanına gösterilen sadakat ve fiyat gösterilmiștir. Kurdukları modelde firma, müssterisi ile fiyat ve teslim zamanı üzerinde pazarlık edebilmektedir. Düșük servis performansının firmanın ününü zedeleyeceği gerçeğinden yola çıkarak, tüm siparişlerin kabul edildiği bir üretim stratejisinin uzun vadede çok da iyi bir strateji olmayacağını vurgulamışlardır.

Moodie ve Bobrowski'nin [4] yaptığı çalışma, sipariş kabul/red kararını destekleyen bir mekanizma olmayip, sadece hangi teslim zamanı tahmin yöntemlerinin ve hangi üretim programlama [Buradaki "programlama" kelimesinin Ingilizce literaturdeki karşılığı "scheduling" kelimesidir. Türkçe literaturde bu kelimenin karşıılığı olarak bazen "çizelgeleme". kelimesi kullanılmaktadır. Fakat biz burada "programlama" kelimesini kullanacağız] kurallarının, hangi pazar senaryolarına daha uygun olacağına ilişkin bir sonuca ulaşmaya yöneliktir. Bizim bu çalışmadan esinlendiğimiz tek şey, yazarlar tarafindan ortaya konmuş olan talep yönetimi modelidir. Fakat bu modelin de bazı eksik yönleri vardır. $\mathrm{Bu}$ modeldeki bir varsayıma göre, siparişlerin reddedilmesi durumunda gelecek potansiyel müșteri siparişleri etkilenmemektedir. Aslinda eğer reddedilen müşteri firma için değerli bir müşteri ise bu durum firmanın gelecekteki sipariş akışııı etkileyecektir. Diğer yandan, Moodie ve Bobrowski'nin [4] modeli tek iş-tek istasyon üretim atölyesi için düşünülmüș olduğundan birden fazla is üretebilen çok istasyonlu üretim atölyelerindeki esnek üretim seçeneklerini göz önünde bulundurmamaktadır. Öyle ki, müșteriler firmayı sadece fiyat ve servis performansı ile değil, sundukları ürün çeșitlerine ve esnekliğe göre de değerlendirebilirler. $\mathrm{Bu}$ nedenle, sipariş kabul mekanizması oluşturulurken çok istasyonlu üretim sistemlerinin karmaşık yapısı da đüşünülmelidir.

Giriş bölümünde de değinildiği gibi, bu çalışmanın hedef aldığı kitle, hem yoğun rekabet altında olan ve hem de üretim kapasitesi pazar talebini karşılamada yetersiz kalan işletmelerđir. $\mathrm{Bu}$ işletmelerin sipariş $\mathrm{kabul} / \mathrm{red}$ kararı konusunda karş1laştıkları problemlerin çözülebilmesi için, bu kararı etkileyecek olan tüm faktörlerin göz önünde tutulduğu bir modele ihtiyaç vardır. Literatürde bu konu ile ilgili yapilan çalışmaların yukarıda belirttiğimiz eksikliklerini gidermek amacıyla kavramsal bir sipariş kabul/red karar modeli geliştirilmiştir.

\section{KAVRAMSAL SIPARIŞ̧ KABUL/RED KARAR MODELI}

Sipariş kabul/red kararını verecek olan birim bazı durumlarda satış departmanı, bazı durumlarda üretim departmanı ve bazı durumlarda da üretim departmanı ile satış departmanının işbirliği halinde bulunduğu ortak bir karar alma organı olabilir. Hangi durum söz konusu olursa olsun, burada kurulacak olan modelde, gerek satış bölümünden gerekse de üretim bölümünden her türlü verinin kolayca sağlanabileceği bir organizasyon yapısı varsayılmıştır. $\mathrm{Bu}$ varsayıma en yakın yapının satış ve üretim departmanlarının bir arada karar verdiği durum. olduğ düşünülebilir.

Karar mekanizmasına girdiler müşterilerden, üretim bölümünden, satış bölümünden ve üst yönetimden gelecektir. Karar mekanizmasının çıktısı ise kabul veya red kararıdır. Kabul kararı siparişin üretim bölümüne iletilmesi ve üretim sürecinin başlatılması anlamına gelecek, red kararı ise siparişin kaybı anlamına gelecektir. Sipariş kabul/red karar modelinin girdi ve çıtıtıları Şekil.1'de görülebilir.

Şekil.l'e bakılacak olursa, sipariş kabul/red mekanizmasına ilk girdi müşteriden gelmektedir. Müşteri, sipariş talebi ile birlikte istediği ürün tipi, ne miktarda istediğini ve ne zaman istediğini işletmeye bildirecektir. Üst yönetimden gelen müşsteri değeri bilgisi, müşterilerin geçmişte firmadan ne kadar stklıkla mal almıs olduğuna bağlı olarak değerlendirilebilir.

Yani müşteri geçmişte firmadan ne kadar fazla alış yapmışsa değerinin o kadar fazla olacağı varsayılmaktadır. Değeri yüksek olan müşteriler için üst yönetim kendi özel inisiyatifini kullanarak kabul/red kararını etkileyebilir.

Satı̧̧ bölümünün sipariş kabul/red kararına girdisi fiyat olacaktır. Buradaki fiyat, müşteri ile satış bölümünün üzerinde anlaşmış bulunduğu fiyattır. Bu fiyat için önceden bir alt limit bir de üst limit belirlenecektir. Alt limit, işletmenin kabul edeceği en dưşük fiyat seviyesi, üst limit ise müşterinin kabul edebileceği en yüksek ödeme miktarıdır. Üzerinde anlaşılan fiyatın, bu iki değer arasunda bir değer alacağı düşünülebilir. 
Üretim bölümünün girdileri mümkün olan teslim zamanı, üretim kapasitesi ve mevcut iș yükü olacaktır. Mümkün olan teslim zamanı literatürdeki teslim zamanı hesaplama yöntemleri kullanılarak belirlenebilir. Üretimdeki mevcut iş yükü, sipariş kabul/red kararı için önemli bir etkendir. Mevcut iş yükü, siparişi istenen zamanda teslim etmeye elverişli değilse, siparişin red edilmesi söz konusu olacaktır. Üretim kapasitesi ve mevcut iş yükü, makine ve insan gücünün birim zamanları cinsinden ölçülebilir.

Portresini giriş bölümünde çizmiş olduğumuz, talebi kapasitesinden büyük olan yoğun rekabet altındaki firmalar için, siparişlerin firmaya geldikten sonra üretime geçildiği düşünülür. Yani, sipariş gelmeden önce bitmiş ürün stoğu yapılmaz. Bu durumlarda, gelen siparişin stoktaki hazır ürünlerden karşılanması olanağı vardır. Fakat burada böyle bir olanak söz konusu olmadığından, modelimizde mevcut stok düzeyi ile ilgili bir girdiye ihtiyaç duyulmamaktadır.

Tüm girdiler verildiğinde, sipariş kabul/red mekanizması siparişi kabul veya red eder. Kabul edilmesi halinde sipariş üretime alınır. Red edilmesi halinde ise, müşteri başka bir firma ile anlaşacak ve bu durum bir kayıp olarak kaydedilecektir. Bir siparișin kabul veya red edilmesi konusunda, hangi kararın en doğru olduğunu belirlemek amacryla belirli performans ölçütleri saptanarak ölçìm yapılmalıdır. $\mathrm{Bu}$ performans ölçümlerine bakılarak her iki türlü kararın sonuçları görülebilir.

Sipariş kabul/red kararının değerlendirilmesinde kullanilabilecek bazı performans ölçütleri şunlardır:gecikme süreleri ortalaması, geciken siparişlerin yüzdesi, akıș zamanları ortalaması, üretim sisteminin kullanım oranı (utilization) ve toplam getiri (satış gelirleri - erken üretim/gecikme maliyeti).

\section{A. Bağımsız Değişkenler}

Geliştirilen modelin bağımsız değişkenleri aşağıda sıralanmaktadır:

a) Sipariş gelişleri arası süre (SGAS); bu süre iki sipariş gelişi arasındaki süredir. Bu değişkenin alacağ değere göre imalathanedeki iş yuikü seviyesi belirlenebilir. Buradan yola çıarak, model farklı iş yükü seviyeleri altında işletilerek, farklı talep seviyeleri için performans ölçülerinin nasıl değiştiği gözlemlenebilir. Literatürde de, benzer şekilde, iş yükünün farklı seviyeleri için sipariş kabul/red mekanizmalarının performanslarını inceleyen araştırmacılar bulunmaktadır (örneğin, Kate [6], Philipoom ve Fry [2]).

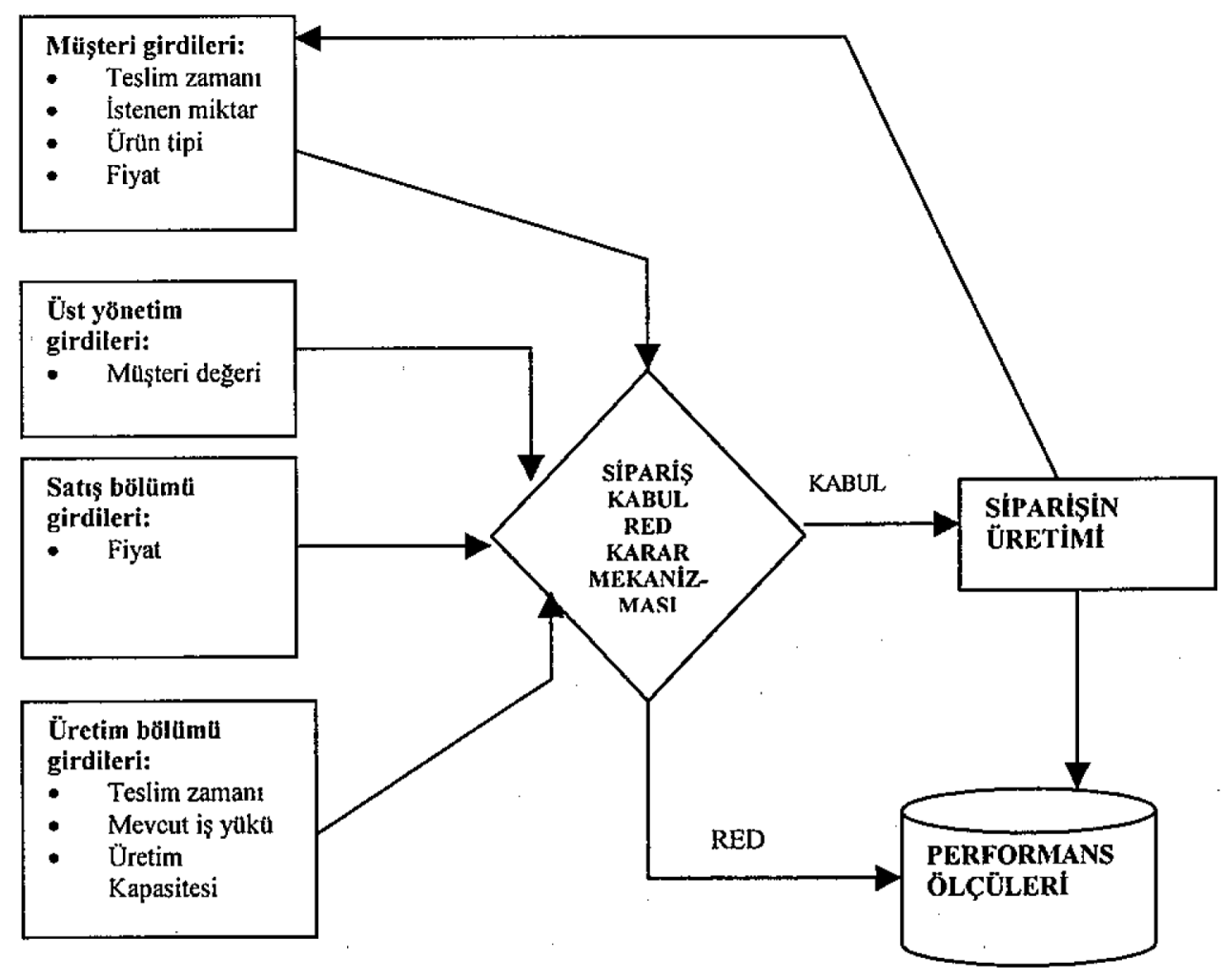

Şekil.1: Sipariş Kabul/Red Karar Modelinin Girdileri ve Çıktıları 
b) Iskonto oranlart (IO); mutabakata varılan fiyat üzerinden, eğer sipariș miktarı belli seviyeleri aşıyorsa, belli oranlarda sskonto (indirim) yapılabilecektir. Kesikli iskonto modelleri olarak bilinen bu tür modellerde, örneğin, müșteri eğer 500 adetten fazla siparis veriyorsa, $\% 5$ gibi bir iskonto oranı uygulanmaktadır. Yine ayn müşteri 1000 adet sipariş ederse $\% 10$ gibi daha yüksek bir Iskonto uygulanmaktadır. Burada sunulan modelde, iki seviyeli bir kesikli iskonto modeli varsayılmaktadır. $Q_{1}$ ve $\mathrm{IO}_{1}$ değerleri, strasıyla, birinci 1skonto seviyesi için gerekli sipariş miktarını ve bu seviyede uygulanacak olan sskonto oranını temsil etmektedir. Aynı şekilde, $\mathrm{Q}_{2}$ ve $\mathrm{IO}_{2}$ degerleri de, sırasıyla, ikinci sskonto seviyesi için gerekli sipariş miktarmı ve bu seviyede uygulanacak olan ıskonto oranını temsil etmektedir. Bazı durumlarda her iki seviyede sskonto uygulanabileceği gibi, bazı durumlarda da sadece bir tek sskonto seviyesi uygulanabilir. Yine bazı durumlarda ise hiçbir iskonto uygulaması söz konusu olmamaktadır. Iskonto uygulanmadığı durumda bu değişkenler sıfır değerlerini alacaktır.

c) Fiyat tespiti: Literatürde sipariş seçim problemi üzerine yapılmış çalışmalarda, siparişin fiyatı genellikle bir olasillk fonksiyonu şeklinde ele alınmış ve beklenen sipariş fiyatı hesaplanmıştır. Gerçek hayatta ise, müșteri ile işletme arasında fiyat konusunda bir pazarlık söz konusudur. Moodie ve Bobrowski [4], müşteri ile işletme arasında fiyat ve/veya teslim zamanı üzerinde pazarlık yapıldığının varsayıldığı bir model geliştirmişlerdir. Fiyat pazarlığmda, eğer müșterinin ödemeyi göze aldığı maksimum fiyat, işletmenin minimum fiyatından daha düșükse, müşteri siparişi vermekten vazgeçmektedir. Aksi takdirde, mutabakata varılan fiyat, müșterinin maksimum fiyatı ile işletmenin minimum fiyatının ortalaması olmaktadır. Burada, mutabakata varılan fiyatın belirlenmesinde Moodie ve Bobrowski'nin [4] modelinde kullanılan yaklaşıma benzer bir yol izlenecektir. Fiyat ve teslim süresi pazarlığı için üç farklı seçenek değerlendirilecektir. Birinci seçenekte sadece fiyat üzerinde pazarlık edildiği varsayılır. İkinci seçenekte sadece teslim süresi üzerinde pazarlık yapılır. Üçüncü seçenekte ise hem fiyat hem de teslim süresi üzerinde pazarlık yapilır.

d) Teslim süresi tespiti: Literatürde sipariş seçim problemine yönelik çalıșmalarda, teslim sürelerine ilişkin olarak farklı varsayımlar yapılmıştır. Örneğin, Philipoom ve Fry [2] ve Kern ve Guerrero [8], teslim sürelerinin müşteri tarafindan belirlendiğini ve sabit olduğunu varsaymıșlardır. Wester ve diğerleri [5], bir teslim süresi değişkeni (slack variable) kullanarak, gevşek ve sıkı olmak üzere iki farkli seviyede teslim süresi belirlemişlerdir. Kate'in [6] çalışmasında $\mathrm{da}$, benzer şekilde, düșük ve yüksek olmak üzere iki farklı teslim süresi seviyesi varsayılmıștır. Lee ve Kim [7] her bir siparişin teslim süresinin müşteri tarafindan belirlendiğini ve bir uniform dağılıma uygun olarak hesaplandığını varsaymıșlardır.

Bütün bu çalsşmaların hepsi de, teslim sürelerini müşterinin belirlediǧini varsaymaktadır. Halbuki gerçek hayatta, şsletme ile müşterinin pazarlık ettiği konulardan biri de teslim süresidir. Teslim sürelerinin belirlenmesinde işletmenin üretim departmanı da söz sahibi olabilir. Moodie ve Bobrowski [4], müşteri ile işletmenin hem fiyat hem de teslim süresi üzerinde pazarlık ettiğini varsayan bir model geliştirmişlerdir. Bu modele benzer bir yaklaşımın burada da kullanılacak olmasına rağmen, iki yaklaşım arasında önemli bir fark olacaktır. Şöyle ki, Moodie ve Bobrowski'nin [4] modelinde teslim süresi ile fiyat arasında birebir bir ilişki olduğu varsayılarak bir eğri çizilmektedir (Bu eğri, önceden ortaya atılmış olan Raifa'nın [18] mutabakat teorisinde kullandığı eğriden alıntı yapılmıştır). Örneğin, firmanın erken teslim için öngördügü bir yüksek fiyat ve geç teslim için öngördügü bir de düşük fiyat belirlenmektedir. Bu veriler ışı̆̆ında, Şekil.2'deki gibi bir eğri çizilmekte ve mutabakata varılan fiyatın, bu eğri üzerinde bir noktada olduğu varsayılmaktadır.

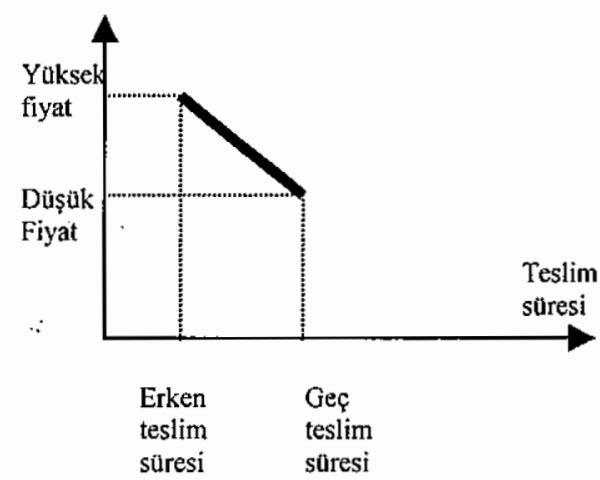

Şekil.2: $\begin{aligned} & \text { Moodie ve Bobrowski'nin Modelindeki Fiyat } \\ & \text { ve Teslim Süresi Eğrisi }\end{aligned}$

Moodie ve Bobrowski'nin [4] fiyat ve teslim süresi eğrisí incelendiği zaman, fiyat ve teslim süresi arasında birebir bir ilișki olduğunun varsayıldığı görülecektir. Halbuki, fiyat ve teslim süresi birbirlerine tamamen bağımlı olmak zorunda değildir. $\mathrm{Bu}$ nedenle, bu çalışmada, teslim süresi ve fiyat birbirinden bağımsız olarak ele alınacaktır. Bu amaçla, teslim sürelerine iliş̧kin olarak üç farklı bağımsız değişken tanımlanacaktır: 1) Müssterinin talep ettiği teslim süresi, 2) Üretim departmanının belirlediği teslim süresi, ve 3) Mutabakata varılan teslim süresi.

Müşterinin talep ettiği teslim süresi (MTTS); müșterinin siparişi verirken talep ettiği teslim süresidir. Müșteri, talep ettiği teslim süresi için belli bir tolerans payına sahip olabilir. Örneğin, teslim süresi için 12 gün talep eden bir müşteri, işletmeye direkt olarak söylemese de, belki 5 gün gibi bir toleransa sahip olabilir. Diğer bir 
değişle, 17 güne kadar olabilecek teslim sürelerini de kabul edebilir. Fakat, bu bilgi işletmenin genellikle ulaşamayacağı (istisnalar olabilir) bir bilgidir. Eğer bir talep süresi pazarlığı söz konusu olacaksa, bu pazarlı 12 gün ile 17 gün arasinda bir pazarlık olacaktır. Teslim süresi için müşterinin toleransı $\mathrm{MT}$ değeri ile temsil edilecektir. Müşteri bazı durumlarda teslim süresi belirtmeyebilir. $\mathrm{Bu}$ durumda üretim departmanının belirlediği teslim süresi kullanılabilir.

Üretim departmanının belirlediği teslim süresi (ÜTS); üretime ait ișlemlerin sayılarını, sürelerinin veya kuyrukta bekleyen işlerin sayısının hesaba katılmasıyla belirlenen teslim süresidir. Teslim sürelerinin hesaplanması için literatürde en çok kullanılan belli başlı yöntemlerin beş tanesi şunlardır: (Moodie ve Bobrowski [4], Philipoom ve diğerleri [19]):

1) Toplam iş kapsamı (Total work content, TWK); bu yöntemde, siparişe ait işlem süreleri kullanılarak teslim süresi belirlenmektedir. $\mathrm{Bir}$ i işinin tahmin edilen akış zamanı (flow time, $F_{i}$ ), toplam işlem zamanının $\left(P_{i}\right)$ bir fonksiyonudur ve yine tahmin edilmesi gereken bir $\mathrm{k}$ parametresi de hesaba katılmalıdır. $\left(F_{i}=P_{i}\right)$

2) İşlem sayısı (Number of Operations, NOP); bu yöntemde, siparișin gerektirdiği işlemlerin sayısına göre bir teslim süresi belirlenir. Bir i işinin tahmin edilen akış zamanı $\left(F_{i}\right)$, i işinin rotası üzerindeki işlemlerin sayısının $\left(\mathrm{N}_{\mathrm{i}}\right)$ bir fonksiyonudur. Yine farklı bir $\mathrm{k}$ parametresinin tahmin edilmesi gerekir. $\left(\mathrm{F}_{\mathrm{i}}=\mathrm{kN}_{\mathrm{i}}\right)$

3) Kuyruktaki görevler (Jobs in Queue, JIQ); bu yöntemde, sırada bekleyen işler göz önünde tutularak teslim süresi belirlenir. Bir $\mathrm{i}$ işinin üretim için atölyeye verildiği anda, atölyede $\mathrm{i}$ işinin rotası üzerinde bulunan bütün iş merkezlerinde, kuyrukta beklemekte olan işlerin sayıları toplanarak ( $\mathrm{JIQ}_{\mathrm{i}}$ ) değeri bulunur. $\mathrm{Bu}$ atölye bilgisi işe ait bir bilgi olan $P_{i}$ ile birleştirilerek $F_{i}$ bulunur. $\left(\mathrm{F}_{\mathrm{i}}=\mathrm{k}_{1} \mathrm{P}_{\mathrm{i}}+\mathrm{k}_{2} J \mathrm{IQ}_{\mathrm{i}}\right)$

4) Kuyruktaki işler (Work in Queue, WIQ); bu yöntem üçüncü yöntemin aynısı olmakla beraber, tek farkı burada, kuyrukta bekleyen işlerin 'sayısı yerine toplam işleme zamanlarının hesaplanmasıdır. Atölyede $\mathrm{i}$ işinin rotası üzerinde bulunan bütün iş merkezlerinde, kuyrukta beklemekte olan işlerin toplam işlem süreleri kümülatif olarak toplanarak (WIQ $)$ ) değeri bulunur. $\mathrm{Bu}$ atölye bilgisi işe ait bir bilgi olan $P_{i}$ ile birleştirilerek $F_{i}$ bulunur. $\left(F_{i}=k_{1} P_{i}+k_{2} W_{I Q}\right)$

5) Müşterinin teklifini kabul et (Accept the customer's estimate strategy, ACE); müşterinin öne sürdüğủ teslim süresi şartsız olarak kabul edilir.

Mutabakata varlan teslim süresi (MVTS); müşteri ile işletmenin pazarlık sonucu üzerinde anlaştığı teslim süresidir. Eğer üretim departmanının belirlediği teslim süresi (ÜTS), müşterinin teslim süresi tolerans limitini aşmıyorsa, sipariş kabul edilir. Bu toleransın en üst limitini aşıyorsa, o halde sipariş red edilir. Burada önemli bir nokta şudur $\mathrm{ki}$, yukarıda belirtilen teslim süresi hesaplama yöntemlerinin (TWK, NOP, vb. gibi) her biri farklı sonuç vereceginden, bazı yöntemlerle müşterinin kabul edebileceği teslim süreleri ortaya atılırken bazı yöntemlerle de kabul edilemeyecek teslim süreleri öne sürülebilir. $\mathrm{Bu}$ nedenle, kullanılan teslim süresi hesaplama yöntemi siparişlerin kabul/red kararını etkileyebilecektir.

e) Sipariş Miktarı (SM); müşterinin sipariş ettiği üründen talep ettiği miktardır. Burada kesikli üretim üzerine yoğunlaştığımız için bu miktar adet olarak ölçülmelidir. SM iskonto oranlarıntn belirlenmesinde ve kapasite ayırmada kullanılır.

f) Müşteri değeri (MD); bir müşterinin işletmeden daha önce yapmış olduğu alışlar göz önünde tutularak işletme için ne derece önemli bir müşteri olduğunu gösteren sembolik bir değerdir. Bu değişkenin üç farkl değer alabileceği varsayılmıştır. Eğer bu değer 1 ise müşteri en önemli müşterilerden, 2 ise orta derecede önemli müşterilerden, 3 ise normal müşterilerdendir. Müşteri değeri, fiyat ve teslim zamanı açısından anlaşmazlığa neden olan siparişlerin, üst yönetimin kararıyla, öncelik kazanmalarına ve kabul edilmelerine sebep olabilir.

g) Mevcut iş yükü hesaplama yöntemi (MIYY); sipariş geldiği anda imalathanedeki mevcut işlerin üretimi için gereken toplam üretim zamanıdır. Philipoom ve Fry'ın da [2] belirttiği gibi, mevcut iş yükü iki şekilde hesaplanabilir. Birinci yöntemde, atölyedeki toplam iş yüküne göre hesaplama yapılmaktadır. İkinci yöntemde ise, sadece yeni gelen siparișin ziyaret edeceği makinalardaki toplam iş yüküne bakılmaktadır. Bu makinaların her biri için mevcut iş yüküi, bu makinalara yönlendirilecek olan tüm işlerin işlem zamanlarının toplanmasi yoluyla bulunmaktadır. Philipoom ve Fry [2] her iki yöntemi de kullanarak bunları birbirleriyle karşılaştırmıș ve ikinci yöntemin daha iyi sonuç verdiğini belirtmişlerdir.

\section{B. Bağımlı Değișkenler}

Kavramsal modelin bağımlı değişkenleri aşağıda siralanmaktadir:

a) Gecikme süreleri ortalamast (GSO); belirli bir planlama dönemi içinde, mutabakata varılan teslim tarihini aşan teslimatlar için, her siparişin gecikilen gün sayısı kümülatif olarak toplanır ve geç teslimat sayısına bölünür. Buradaki gecikme sadece pozitif gecikmedir. Yani negatif gecikme ya da diğer bir değişle erken 
teslimatlar bu hesaba katılmaz. Ayrıca burada, en yüksek ve en düşük gecikme süreleri de belirlenmelidir.

b) Geciken siparişlerin yüzdesi (GSY); belirli bir planlama dönemi içinde, gecikmeli teslimat sayısının toplam teslimat sayısına oranının 100 ile çarpılmasıyla elde edilir. Ayrıca, geciken her siparişin sipariş miktarı da bilinmektedir.

c) Akış zamanı ortalaması (AZO); siparişlerin üretimi için geçen toplam sürelerin ortalamasıdır. Bu süre ne kadar uzun ise yarı mamul stoklarinı seviyesi de (WIP) o kadar yüksek demektir.

d) Üretim sisteminin kullantm orant (ÜSKO); Üretim sistemindeki makinaların ne kadar üretken kullanıldığını ve ne kadar boș durduklarını gösteren bir yüzdedir.

e) Siparişin toplam katkısı (STK); bir siparişin işletmeye sağlayacağı gelirlerden sabit maliyetlerin ve siparişin erken ya da geç üretilmesinden kaynaklanabilecek olan elde tutma ya da gecikme maliyetinin çıkarılmasıyla elde edilir.

\section{Varsayımlar}

Modelimizin uygulanmasındaki bazı varsaymmlar aşağıda sıralanmaktadır:

a) Bir siparişin ya tümü kabul edilir ya da tümü red edilir, siparişlerin kısmi kabulünün mümkün olmadığı varsayılmaktadır.

b) Bir siparişin sadece tek bir ürün tipini kapsadtğ1 varsayılmaktadır. Bu durumda, eğer birden fazla ürün tipini kapsayan siparişler varsa, bunlar ayrı ayrı siparişlermiş gibi düşünülecektir. Doğal olarak, bu siparişler aslında aynı müşteriye gideceği için mutabakata varılan teslim zamanları aynı olacaktrr. Bu varsayım sadece model için geçerli olup, gerçek hayatta bunun böyle olması şart değildir.

c) Üretim kapasitesi kısa vadede sabit varsayllacak ve ilave kapasitelerin (yeni tesisler, vb.) mümkün olmadığı varsayılmaktadır.

\footnotetext{
d) Üretime girmiş bir siparişin üretim programındaki yerinin değiştirilemeyeceği varsayllacaktır. Üretim programundaki değişiklikler sadece henüz üretime girmemiş siparişler üzerinde yapılabildiği düşünülmüştür.
}

\section{Kavramsal Modelin Uygulanmasına Yönelik Gelecek Araştırma Planı}

Burada geliştirilen kavramsal modelin deneysel olarak uygulanabilirliğinin gösterilebilmesi amacıyla, çalışmamızın ikinci aşamasında bir simülasyon modeli geliștirmeyi planlamaktayız. Söz konusu simülasyon modeli ile sipariş kabul/red karar modelinin farklı üretim sistemi koşulları altında nasıl sonuçlar vereceği görülebilecektir. Aşağıta, simülasyon yöntemiyle yapılması planlanan bir takım deney ve analizlere yer verilmektedir.

İs yükünün, örneğin $\% 65$ ile $\% 95$ arasunda yedi farkh değer alacağı varsayılarak her bir yüzdelik dilim için model ayrı ayrı çalıştırılabilir. Bu yedi farklı seviye, aynı zamanda, siparișlerin kabul/red edilme oranlarının da yedi farklı seviyede olması anlamına gelmektedir. Bu farklı koşullar altında, yukarıda belirtilen performans ölçülerinin (gecikme zamanları, vb. gibi) alacağı değerler belirlenebilir.

Diğer yandan, teslim zamanlarının hesaplanması için yukarıda belirtilen beş farkhı yöntem ayrı ayrı kullanılarak hangi koşullarda hangi yöntemin daha iyi sonuç vereceği tespit edilebilir. Buna ilaveten, iş yükünün hesaplanması için yukarıda belirtilen iki ayrı yöntem de (toplam işlem süreleri ya da sipariş rotası üzerindeki işlemlerin süreleri) kullanılarak her iki yöntem birbiriyle kıyaslanır.

Müşsteri değerinin sipariş seçimini etkilediği veya etkilemediği iki ayrı durum, model üzerinde denenebilir. Diğer bir deyişle, iş önceliklerinin olduğu veya olmadığı durumlar klyaslanarak, iş önceliklerinin varlığının sipariş seçim kararı üzerine etkisi incelenir.

Yukarıda saydığımız farklı üretim koşulları önce kapasiteye dayalı sipariş kabul/red mekanizmalarına, sonra fiyata dayalı sipariş kabul/red mekanizmalarma ve en sonunda da hem kapasiteye hem de fiyata dayalı sipariș kabul/red mekanizmalarına uygulanarak bu iki farklı yaklaşımın birbirleriyle kıyasłanması mümkün olur.

Simülasyon sonucunda, siparișlere ait akış zamanları, gecikme süreleri, toplam getiriler vb. gibi veriler toplanacak ve bu veriler işığında farklı üretim koşullarında hangi uygulama ya da yaklaşımların daha iyi sonuçlar verdiği gözlemlenebilecektir. 


\section{SONUÇ}

Burada kavramsal olarak ele aldığımız sipariş kabul/red kararı, günümüz işletmelerinin aslında farkında olmadan ve bazen de gerekli önemi vermeden geçiştirdikleri bir konu olmaktadır. Kâr amaçlı hiçbir işletme müşterisini red etme fikrini kabul etmek istemez, fakat üretim kapasitesinin talebi karşılayamadı̆̆ durumlarda, müssterilerin bir kısmı ya red edilecektir ya da sipariş kabul edilse bile teslimatta gecikmeler olabileceginden müşteri mutsuz olabilecektir. Daha da önemlisi, müșteri eğer zamanında elde etmek istediği ürüne bir miktar fazla para vermeyi gözden çikariyorsa, bu müşterinin getirisi diğerlerinden fazla olabilecektir. Bütün bu faktörlerin göz önünde bulundurularak, mevcut kapasitenin en iyi getiriyi sağlayacak şekilde kullanılması ve bunu yaparken de müşterilerin mümkün mertebede memnun edilmesi önemli bir konudur. Burada kavramsal olarak ortaya konmaya çalışılan bir model ile bu problem ele alınmış ve işletmelerde siparişlerin optimum şekilde kabul / red edilmesi konusunda sayısal yöntemlerden faydalanılabileceğine ilişkin yeni bir araştırma alanına ışık tutulmuş̧ur. 


\section{YARARLANILAN KAYNAKLAR}

[1] Weng, Z.K., "Manufacturing Lead Times, System Utilization Rates and Lead-Time-Related Demand", European Journal of Operational Research, Vol. 89, 1996, ss.259-268.

[2] PHILIPOOM, P.R.; FRY, T.D., "Capacity-based Order Review/Release Strategies to Improve Manufacturing Performance", International Journal of Production Research, Vol. 30, No: 11, 1992, ss.2559-2572.

[3] MERIT, D., "Bravery the Key to Job Scheduling", American Printer, Vol. 205, 1990, s. 126.

[4] MOODIE, D. R.; BOBROWSKI, P. M., "Due Date Demand Management: Negotiating the Trade-Off Between Price and Delivery", International Journal of Production Research, Vol. 37, No:5, 1999, ss.997-1021.

[5] WESTER, F.A.W; WIJNGAARD, J.; ZIJM, W.H.M., "Order Acceptance Strategies in a Production-to-Order Environment with Setup Times and Due-Dates", International Journal of Production Research, Vol. 30, No: 6, 1992, ss. 1313-1326.

[6] KATE, ten H. A., "Towards A Better Understanding of Order Acceptance", International Journal of Production Economics, Vol. 37, 1994, ss.139-152.

[7] LEE, D.H.; KIM, Y.D., "Iterative Procedures for MultiPeriod Order Selection and Loading Problems in Flexible Manufacturing Systems", International Journal of Production Research, Vol. 36, No: 10, 1998, ss.26532668.

[8] KERN, G.M.; GUERRERO, H.H., "A Conceptual Model for Demand Management in the Assemble-to-Order Environment", Journal of Operations Management, Vol. 9, No: 1, January 1990, ss.65-84.

[9] KERN, G.M., "How to More Effectively Accept and Refuse Orders," Production and Inventory Management, Vol. 29, No: 4, 1988, ss.59-63.

[10] BALACHANDRAN, K.R.; SCHAEFER, M.E., "Optimal Acceptance of Job Orders", International Journal of Production Research, Vol. 19, No: 2, 1981, ss.195-200.
[11] MATSUI, M., "Job-Shop Model: A M /(G,G)/1(N) Production System with Order Selection", International Journal of Production Research, Vol. 20, No:2, 1982, ss. 201-201.

[12] MATSUI, M., "Optimal Order-Selection Policies for A Job Shop Production System", International Journal of Production Research, Vol. 23, No: 1, 1985, ss.21-31.

[13] MATSUI, M.; YANG, G.; MIYA, T., "Optimal Control of a Job-Shop Production System with Order-Selection and Switch-Over", International Journal of Production Research, Vol. 37, No: 1, 1999, ss.73-90.

[14] HARRIS, Frederick H.; PINDER, Jonathan P., "A Revenue Management Approach to Demand Management and Order Booking in Assemble-to-Order Manufacturing", Journal of Operations Management, Vol. 13, No: 4, December 1995, ss.299-309.

[15] FRANSOO, Jan C., "Demand Management and Production Control in Process Industries", International Journal of Operations \& Production Management, Vol. 12, No: 7/8, 1992, ss.187-196.

[16] BITRAN, G. R.; HAX, A.C., "On the Design of Hierarchical Production Planning Systems", Decision Sciences, Vol. 8, No: 1, January 1977, ss.28-55.

[17] MOODIE, D. R., "Demand Management: the Evaluation of Price and Due Date Negotiation Strategies", Production and Operations Management, Vol. 8, No: 2, Summer 1999, ss.151-162.

[18] RAIFFA, H., The Art and Science of Negotiation, Belknip Press of Harvard University Press, Cambridge MA, 1982.

[19] PHJLIPOOM, P.R.; REES, L.P.; WIEGMANN, L., "Using Neural Network to Determine Internally-Set DueDate Assignments for Shop Scheduling", Decision Sciences, Vol. 25, No: 5/6, 1994, ss.825-851. 